\title{
Hiperglisemi, Oksidatif Stres ve Tip 2 Diyabette Oksidatif Stres Belirteçlerinin Tanımlanması
}

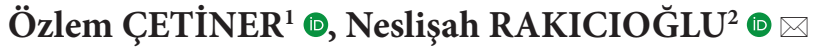 \\ ${ }^{1}$ Atılım Üniversitesi, Sağlık Bilimleri Fakültesi, Beslenme ve Diyetetik Bölümü, Ankara, Türkiye \\ ${ }^{2}$ Hacettepe Üniversitesi, Sağlık Bilimleri Fakültesi, Beslenme ve Diyetetik Bölümü, Ankara, Türkiye
}

Bu makaleye yapılacak atıf: Çetiner Ö, Rakıcıŏlu N. Hiperglisemi, Oksidatif Stres ve Tip 2 Diyabette Oksidatif Stres Belirteçlerinin Tanımlanması. Türk Diyab Obez 2020;1: 60-68.

\begin{abstract}
ÖZET
Oksidatif stres, hem Tip 2 diyabet oluşumu hem de diyabet komplikasyonlarının gelişiminde rol oynayabilen önemli bir aktördür. Temel olarak oksidatif stres, reaktif oksijen türevlerinin (ROS) yapımı ve bozunumu arasındaki dengenin bozulması sonucunda oluşan fizyolojik durumu tanımlamada kullanılır. Klinik çalışmalar sonucu elde edilen veriler, sistemik oksidatif stresin metabolik sendrom ve komponentleriyle yakından ilişkili olduğunu göstermektedir.

Kronik hiperglisemi ve hiperlipidemi, ROS oluşumu için önemli risk faktörleridir. Hipergliseminin, ROS birikimine katkısı farklı metabolik yolaklar üzerinden gerçekleşebilmektedir. Temel olarak hiperglisemik koşullarda glikolitik yolağın aktivitesinin artması ve mitokondriyal elektron taşıma sistemi üzerinde oluşan elektron basıncı, ROS oluşumuna katkı sağlar. Reaktif oksijen türevlerinin oluşumu ve birikimi daha sonra glikolizde görevli kilit enzimlerden gliseraldehit 3-P dehidrogenaz (GAPDH) enzim aktivitesini baskılayarak hücreyi, glikozu alternatif yolaklarla metabolize etmeye zorlar. Glikoliz ve krebs döngüsünün etkinliği azalır; polyol yolağı, hekzozamin yolağı ve protein kinaz C (PCK) aktivitesi artar. Tüm bu alternatif metabolik yolaklar hücrede ROS oluşumunu daha da artırır. ROS birikimi, insülinin gen ekspresyonunu ve beta hücrelerden insülin salınımını posttranslasyonel faktörler aracıllğıyla azaltarak, insülin direnci patogenezine katkı sağlayabilir. Hiperglisemi kaynaklı ROS birikimi, diyabet komplikasyonlarının oluşumunda da önemli role sahiptir. Klinik çalışmaların sonuçları, diyabet ve komplikasyonlarının, hücrenin protein, lipit ve nükleik asit komponentlerinde yarattığı oksidatif hasarı belirlemede pek çok belirtecin kullanılabileceğini ve bu belirteçlerin oksidan harabiyetin düzeyi hakkında fikir verebileceğini göstermektedir.
\end{abstract}

Anahtar Sözcükler: Hiperglisemi, Reaktif oksijen türevleri, Alternatif metabolik yolaklar, Tip 2 diyabet

\section{Hyperglycemia, Oxidative Stress, and Identification of Oxidative Stress Parameters in Type 2 Diabetes}

\begin{abstract}
Oxidative stress is an important actor that can play a role in both the development of Type 2 diabetes and the development of diabetes complications. Basically, oxidative stress is used to describe the physiological state resulting from the disruption of the balance between the production and degradation of reactive oxygen derivatives (ROS). Data obtained from clinical studies show that systemic oxidative stress is closely related to metabolic syndrome and its components.

Chronic hyperglycemia and hyperlipidemia are important risk factor for ROS formation. The contribution of hyperglycemia to ROS accumulation can occur through different metabolic pathways. Increased activity of the glycolytic pathway under hyperglycemic conditions and electron pressure on the mitochondrial electron transport system contribute to ROS formation. The formation and accumulation of reactive oxygen derivatives forces the cell to metabolize glucose with alternative pathways by suppressing the activity of glyceraldehyde 3-P dehydrogenase (GAPDH) enzyme which is one of the key enzymes involved in glycolysis. While the effectiveness of the glycolysis and krebs cycle decreases, polyol pathway, hexosamine pathway and Protein Kinase C (PCK) activity increase. All of these alternative metabolic pathways further increase ROS formation in the cell. ROS accumulation may contribute to the pathogenesis
\end{abstract}

ORCID: Özlem Çetiner / 0000-0001-9872-416X, Neslişah Rakıcıŏlu / 0000-0001-8763-7407 
of insulin resistance by reducing the gene expression of insulin and the release of insulin from beta cells via posttranslational factors. ROS accumulation due to hyperglycemia also plays an important role in the development of diabetes complications. The results of clinical studies indicate that many markers can be used to determine the oxidative damage caused by diabetes and its complications in the protein, lipid and nucleic acid components of the cell and these markers may also give an idea about the level of oxidant damage.

Key Words: Hyperglycemia, Reactive oxygen species, Alternative metabolic pathways, Type 2 diabetes

\section{GİRIş}

Oksidatif stres; kanser, diyabet ve diğer pek çok kronik hastalığın patogeneziyle yakından ilişkili fizyolojik bir durumdur. Vücutta reaktif türevlerin oluşumu, hücrenin protein, lipit ve nükleik asit yapısına zarar vererek, hücre fonksiyonunu bozabileceği gibi hücreyi apoptozise kadar götürebilir. Diyabette oksidan bileşikler özellikle beta hücre fonksiyonlarının bozulabilmesine ve niceliksel anlamda azalmalarına sebebiyet verebilir. Bu derleme makalenin amac1, oksidatif stres ve hiperglisemi ilişkisini incelemek ve diyabetik bireylerdeki oksidatif stres belirteçlerini tanımlamaktır.

\section{Hiperglisemi ve Oksidatif Stres İlișkisi}

Reaktif oksijen türevlerinin üretimi vücutta, egzojen indükleyicilerin yanı sıra enfeksiyonlar, iskemi-reperfüzyon (I/R) hasarı ve çeşitli inflamatuar süreçler ile de artış gösterebilmektedir (1). Kronik hiperglisemi ile seyreden diyabet, vücutta inflamatuar bir ortam oluşturarak reaktif oksijen türevlerinin oluşumu için önemli zemin oluşturur. Reaktif oksijen türevlerinin üretimindeki artış ve antioksidan konsantrasyonlarının azalmasıyla görülen oksidatif stres, uzun dönem yüksek seyreden plazma glikoz seviyeleriyle ilişkilendirilmektedir (2).

Temel olarak hiperglisemik koşullarda glikolitik yolağın aktivitesinin artması, mitokondride Nikotinamid adenin dinükleotit (NADH) birikimiyle sonuçlanır. NADH, mitokondriyal elektron taşıma sistemi üzerinde elektron basincina sebep olur ve mitokondri, artan NADH konsantrasyonunu azaltmak için NADH oksidasyonunu artırır. NADH'nin NAD'a yükseltgenmesi sırasında oluşan elektron kaçakları sonucu da süperoksit radikalleri oluşur. Süperoksit, diğer tüm reaktif oksijen türevlerinin prekürsörü olup, süperoksit seviyelerinin artışı oksidatif stres oluşumunda rol oynar (3). NADH seviyelerindeki değişim sonucu oluşan ROS, daha sonra oksidatif modifikasyonlara hassas olan gliseraldehit-3 fosfat dehidrogenaz (GADPH) enzim aktivitesini de bozar. GADPH enzimi glikolitik yolakta, gliseraldehit 3 fosfatın, piruvata dönüşümünden sorumlu olup, aktivitesinde meydana gelen bozukluklar, glikoliz ve Krebs Siklusunun etkinliğini azaltır. Gliseraldehit 3 fosfatın da dahil olduğu ara metabolitler birikir ve alternatif yolaklar ile metabolize edilir (Şekil 1). Bahsi geçen alternatif yolakların metabolizma üzerine etkisi, normoglisemik koşullarda çok minimal ve önemsizdir. Ancak, hiperglisemik koşullarda bu yolaklar, glikoz metabolizmasında öncü hâle gelerek, ROS üretimi, oksidatif stres, diyabet ve komplikasyonlar1nın patogenezinde aktif rol oynar (3). Bu yolaklar aşağıda detaylı olarak incelenmiştir.

\section{Polyol Yolağı}

Glikoz metabolizmasının polyol yolağı, hücre içi glikoz seviyeleri yükseldiğinde aktif hâle gelir. Yolaktaki ilk ve aynı zamanda hız sinırlayıcı enzim olan aldoz redüktaz, NADPH'yi bir kofaktör olarak kullanarak, glikozu sorbitole dönüştürür. Sorbitol daha sonra kofaktör olarak NAD+ kullanan sorbitol dehidrogenaz ile fruktoza metabolize olur (4). Polyol yolağı, hiperglisemik koşullarda, glikozun yaklaşık \%30'unun metabolize edilmesinden sorumludur. Yolağın, oksidatif stres üzerine etkisi iki farklı mekanizma üzerinden açıklanabilir (5). İlk olarak yolakta oluşan metabolitlerin hücre fonksiyonu ve oksidatif stres üzerine etkilerinden söz edilebilir. Bir alkol türevi olan sorbitol, hidrofiliktir ve bu nedenle hücre membranları üzerinde kolaylıkla dağılmaz. Hücre içinde birikerek, hücrenin osmolar dengesini değiştirir. Polyol yolağının son ürünü olan fruktoz ise, fruktoz-3-fosfata fosforile edilebilir (Şekil 2). Fruktoz-3-fosfat daha sonra 3-deoksiglukosona parçalanabilir. Her iki bileşik de ileri glikasyon son ürünlerinin (AGE) oluşumuna giren güçlü glikosile edici ajanlardır (4). Hücrede AGE oluşumunun artışı oksidatif stres ile sonuçlanacaktır. Oluşan metabolitlerin olumsuz etkilerinin yanı sıra, tepkime sırasında kullanılan kofaktörler de hücre içi oksidan/ antioksidan dengesini bozar. NADPH'nin aldoz redüktaz ile kullanımı, glutatyon redüktaz için kofaktör olarak kullanımının daha düşük olmasına ve dolayısıyla hücrede antioksidan olarak görev yapan glutatyon oluşumunun da azalmasina sebep olur (5). Sorbitol dehidrogenazın, kofaktör olarak NAD'ı kullanması sonucunda NADH oluşur. $\mathrm{NADH}, \mathrm{NADH}$ oksidaz için güçlü bir substrattır ve $\mathrm{NADH}$ oksidasyonu sırasında oluşan süperoksit anyonları oksidatif stres oluşumuna katkı sağlar (5). Hayvan çalışmalarından elde edilen sonuçlar, polyol yolağının oksidatif stres üzerine olumsuz etkilerini açıkça göstermektedir. Aldoz redüktaz enzimi çıkarılan hayvanlarda yapılan çalışmalarda; polyol yolağının diyabet kaynaklı oksidatif stresin önemli bir kaynağı olduğu sonucuna ulaşılmıştır $(6,7)$. 


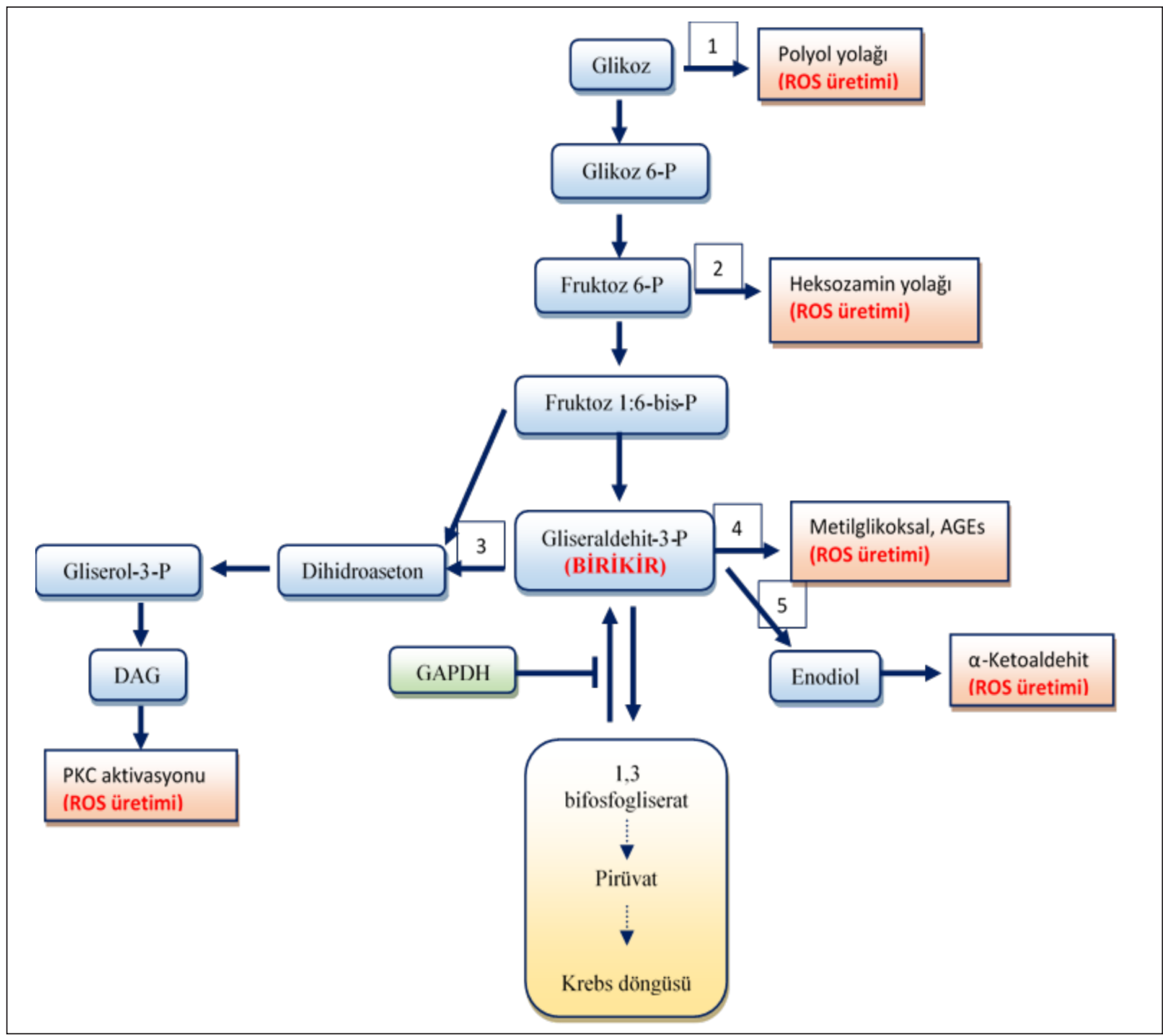

Şekil 1: Gliko oksidatif stres yolakları (3): Hiperglisemik koşullar altında glikolizin etkinliği azalır. Glikolizin hız sınırlayıcı enzimlerinden gliseraldehit-3 fosfat dehidrogenazın (GADPH) aktivitesi, reaktif türevlerin artışını takiben baskılanır ve glikoz alternatif yolaklarla metabolize edilebilir. Bunlar; 1)polyol yolağı, 2)heksozamin yolağı, 3)PKC aktivasyonu, 4)AGE oluşumu, 5) Enodiol yolağıdır. Bu yolakların etkinliğinin artması, hücrede reaktif türevlerin artışıyla sonuçlanır.

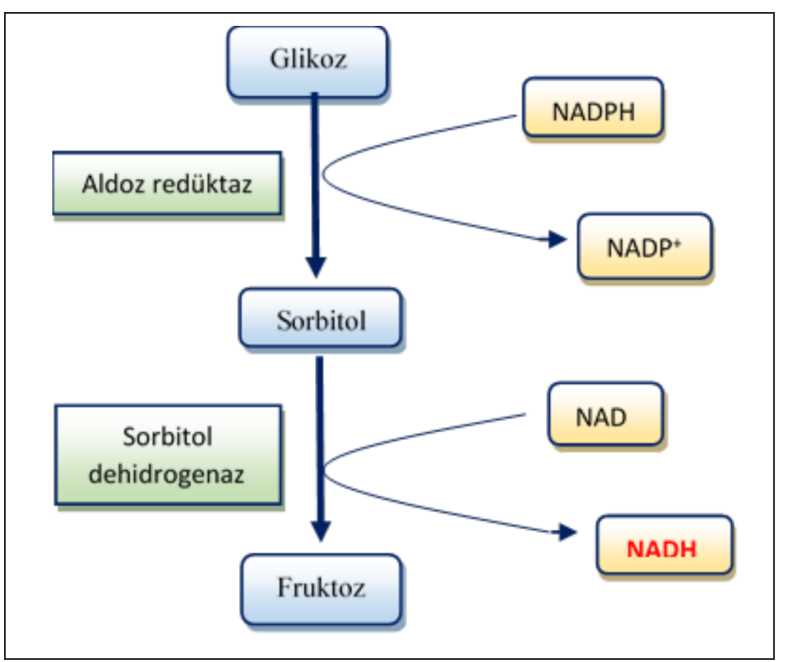

Şekil 2: Polyol Yolağı (3): Hiperglisemik koşullarda etkin yolaklardan bir tanesi de polyol yolağıdır. Bu yolak adımları üzerinde glikoz sorbitol ve fruktoza metabolize olur.
Aldoz redüktaz, sinir, retina, lens, glomerül ve vasküler hücre dokularında bulunur ve bu dokulardaki aktivitesinin artışı diyabetik komplikasyonların patogeneziyle ilişkilendirilebilir (8). Pek çok hayvan çalışmasında, aldoz redüktaz inhibitörlerinin diyabet komplikasyonlarının önlemesinde etkili olabileceği gösterilmiştir (9-11).

\section{Heksozamin Yolağı}

Hiperglisemik koşullarda aktivitesi artan bir diğer yolak da heksozamin yolağıdır. Heksozamin yolağı; normal fizyolojik koşullarda amino şekerlerin sentezinde görevlidir. Glikolitik yolaktaki fruktoz-6-fosfattan, hız sınırlayıcı enzim fruktoz-6-fosfat-amidotransferaz (GFAT) ile glikozamin-6-fosfat ve diğer ara metabolitlerin oluşumunu takiben üridin difosfat-N-asetilglikozamin (UDP-GlucNAc) sentezi ile sonuçlanır (Şekil 3). UDP-GlucNAc, diğer bütün amino şekerlerin prekürsörü olup, glikoproteinlerin, 
proteoglikanların ve glikozaminoglikanların biyosentezi için gereklidir (12). Ayrıca UDP-GlucNAc, sitozolde ve çekirdekte bulunan regülatör proteinlerin post-translasyonel modifikasyonunda da prekürsör olarak görev yapar. Heksozamin biyosentetik yolağının metabolik sinyalizasyonunu içeren bu kolu, heksozamin sinyal yolağ adlandirilır ve UDP-GlucNAc'nin O-glikosilasyonunu içerir (13). O-glikozilasyon sonucu oluşan O-bağlı N-asetil- $\beta$-D-glikozamin (O-GlcNAc), hücresel proteinlerin serin ve treonin rezidülerine bağlanarak hücre döngüsü, immün aktivite, apoptozis, strese cevap, inflamasyon ve transkripsiyonel regülasyon gibi birçok biyolojik süreçte rol oynar (14). Normoglisemik koşullarda heksozamin yolağının glikoz metabolizması üzerine etkisi \%2-5'tir (14). Hiperglisemik koşullarda heksozamin yolağına glikoz akışı artar. Heksozamin yolağının hiperaktivitesi sonucu oluşan glikozamin-6-fosfat, pentoz fosfat yolunun hiz sinırlayıcı enzimi olan glikoz-6-fosfat dehidrogenaz aktivitesini inhibe eder (15). Pentoz fosfat yolu, biyokimyasal bir redüktan olarak görev yapan NADPH'ın başlıca üretildiği yerdir. NADPH, daha önce bahsedildiği gibi glutatyon redüktaz ve katalaz gibi enzimlerin kofaktörü olarak antioksidanların yapı- minda rol oynar ve NADPH miktarının azalması, oksidan/ antioksidan dengesinin bozulmasıyla sonuçlanabilir.

Hiperglisemik koşullarda, heksozamin sinyal yolağının aşırı aktivitesi sonucu oluşan O-GlcNAc, ayrıca insülin direnci oluşum mekanizmasında da görev alabilmektedir. O-GlcNAc, insülin sinyalizasyonunda görevli kilit enzimlerin fosforilasyonunu bozarak insülin aktivitesini etkileyebilmektedir (16). Ratlarda yapılan bir çalışmada heksozamin yolağına glikoz akışının artışı, Glukoz taşıyıcı tip 4 (GLUT4) translokasyonun bozulması ve insülin duyarlılığının azalmasıyla ilişkilendirilmiştir (17).

\section{Protein Kinaz C Yolağı}

Hiperglisemik koşullarda aktivitesi artan bir diğer yolak protein kinaz C (PKC) yolağıdır. Protein kinaz C’ler, serin/ treonin ilişkili protein kinaz enzim ailesini temsil eder ve birçok hücresel fonksiyon ile sinyal iletim yolağında aktif görev alırlar. Bu enzim grubunun aktivitesinin düzenlenmesi normal hücre fonksiyonu için çok önemlidir. Sürekli aktivite gösterdikleri durumda hücrede kontrolsüz büyümeye sebep olabilirler (18). Pek çok PKC çeşidi, diasilgliserol (DAG) miktarındaki artışa hassastır ve DAG artışını

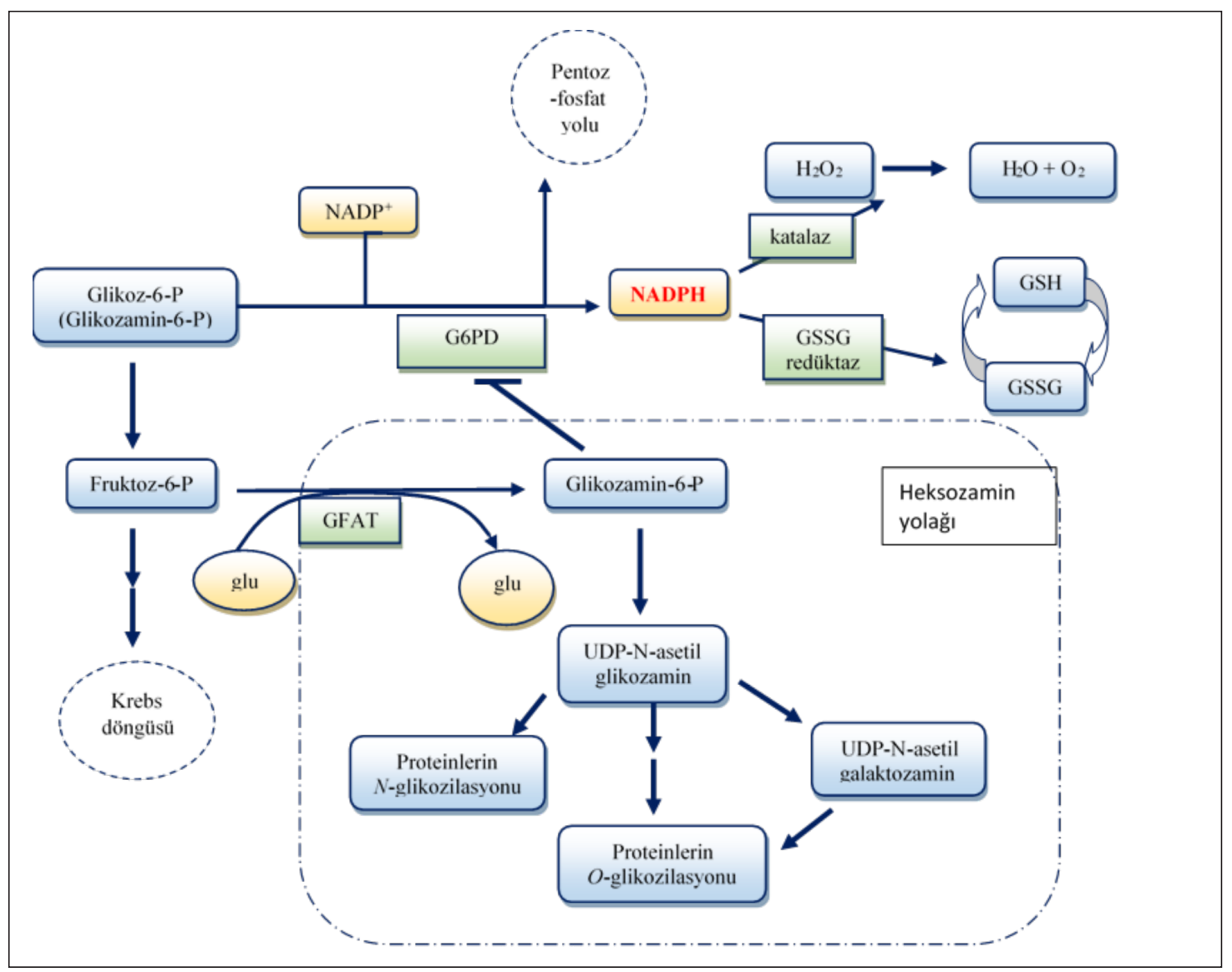

Şekil 3: Heksozamin Yolağı (15): Hiperglisemik koşullarda etkin yolaklardan bir tanesi de heksozamin yolağıdır. Bunun yerine UDP-Nasetilglikozamin (UDP-GlucNAc) diğer ara metabolitlere metabolize olur. 
takiben aktive olurlar. Hiperglisemide dokulara artan glikoz akışı sonucu, gliseraldehit-3-fosfat, transferazlar ve fosfatazlar aracılığıyla gliserol fosfata dönüștürülür. Gliserol fosfat, DAG'ın prekürsörü olup hücrede DAG miktarlarının artışı, PKC enzim ailesinin uyarılmasıyla sonuçlanır (18). Diyabette retina, aort, kalp ve böbrek gibi vasküler dokular ile karaciğer ve iskelet kasları gibi nonvasküler dokularda total DAG seviyeleri artı̧ gösterir. Artan DAG seviyeleriyle aktive olan PKC, vasküler geçirgenlik ve akışın regülasyonu, sitokin üretiminin artışı, bazal membranın kalınlaşması gibi diyabet komplikasyonlarıyla ilişkili pek çok süreçte etkin rol oynar (19). PKC aktivitesi oksidatif denge durumundan da etkilenebilmektedir. Hiperglisemi kaynakl $\mathrm{H}_{2} \mathrm{O}_{2}$ ve mitokondriyal süperoksit, DAG gibi PKC aktivitesinin stimülatörüdür (19). Benzer şekilde oksidatif stres PKC aktivitesinden etkilenebilmektedir. $\mathrm{NAD}(\mathrm{P}) \mathrm{H}$ oksidaz enzimi, $\mathrm{NAD}(\mathrm{P})$ H'nin $\mathrm{NAD}(\mathrm{P})$ 'ye oksidasyonundan sorumludur ve birçok hücrede ROS oluşumunda rol oynar. PKC'nin de içinde olduğu bir grup kinaz, NAD(P)H'nin fosforilasyonunu ve membran translokasyonunu sağlayarak, katalitik olarak aktif hâle gelmesinde etkili olmaktadır (18). NAD(P) $\mathrm{H}$ aktivitesi sonucu oluşan elektron kaçakları ROS üretimine katkı sağlayabilmektedir.

\section{İleri Glikasyon Son Ürünleri (AGE)}

Hiperglisemik koşullarda oluşumu artan ve diyabet komplikasyonlarının patofizyolojisinde ve oksidatif stres oluşumunda etkin rol oynayan bir diğer grup da ileri glikasyon son ürünleridir (AGE). AGE'ler biri enzimatik, biri non-enzimatik olmak üzere vücutta 2 temel mekanizma üzerinden sentezlenebilir. Enzimatik olarak, gliseraldehit3-fosfattan oluşan metilglikoksal, proteinlerin sistein, lizin ve arjinin kalıntılarıyla AGE oluşturabilir. Bunun dışında glikoz, non-enzimatik olarak proteinlerin lizin kalıntılarına direkt bağlanarak, Shiff bazı oluşturabilir. Shiff bazları ise sonrasında daha kararlı ve stabil olan AGE'yi oluşturur (20).

Normoglisemik koşullarda vücutta AGE'nin oluşumu oldukça yavaş ve kısıtlıdır. Ancak hipergliseminin seviyesine ve süresine göre diyabette AGE oluşumu hızlanır ve artar (21). Vücutta birçok protein AGE oluşumuna katılabilir ve bu proteinlerin nicelendirilmesi genellikle diyabetin ilerlemesini ölçmek için bir indeks olarak kullanılmaktadır (20). Hemoglobin, AGE oluşumuna katılan proteinlerden bir tanesidir ve $\mathrm{HbAlc}$ seviyelerinin artışı sıklıkla diyabet komplikasyonlarıyla ilişkilendirilmektedir (22). AGE vücutta, pro-oksidan moleküllerin oluşumuna katkı sağlayarak oksidatif strese sebep olabilmektedir. Hiperglisemi kaynaklı glikotoksisitenin bir ürünü olan AGE, NADPH oksidazı aktifleştirerek, süperoksit oluşumuna katılır. Birçok AGE inhibitörü, oksidatif stresin azaltılması üzerine olumlu etkilere sahiptir (23).

\section{Gliseraldehit Oto - Oksidasyon Yolağı (Enediol Yolağı)}

Hiperglisemide aktivitesi artan ve oksidatif stres birikimine katkı sağlayan bir diğer yolak da gliseraldehit oto-oksidasyon yolağıdır. Gliseraldehit 3-fosfat, glikoliz sırasında fruktoz 1,6 fosfattan oluşan bir ara metabolit olup, hiperglisemik koşullarda GADPH enzim aktivitesinin baskılanması sonucu hücrede birikim gösterir. Artan Gliseraldehit 3-P, oto-oksidasyona uğrar. Bu yolak, potansiyel olarak toksik iki ürünün oluşumuyla sonuçlanır. Bunlardan ilki olan a-ketoaldehitler, AGE oluşumuna; hidrojen peroksit ise aktif redoks metalleri varlığında hidroksil radikallerinin oluşumuna katılabilir (1).

\section{OKSIDDATIF STRESIN TIP 2 DIYYABET PATOGENEZINNDEKI ROLÜ}

\section{Oksidatif Stresin Beta Hücre Fonksiyonu Üzerine Etkisi}

Kan glikoz seviyelerinin uzun dönem normal fizyolojik seviyelerin üzerinde seyretmesi, beta hücrelerdeki insülinin miktar ve fonksiyonunu etkileyebilmektedir. Hiperglisemi ortaya çıktıktan sonra, beta hücre fonksiyonu aşamalı olarak bozulur. Diyabette sıklıkla gözlenen bu süreç "beta hücre glikoz toksisitesi” olarak adlandırılmaktadır. Hiperglisemi ve takip eden oksidatif stres, insülinin gen ekspresyonu ve sekresyonunu bozar ve beraberinde apoptozisi getirir (24). Beta hücrelerde insülin gen ekspresyon kaybı, pankreatik duedonal homebox gen 1 (PDX-1) ve MafA transkripsiyon faktörlerinin ekspresyonun ve/veya DNA bağlanma aktivitelerinin azalması sonucu gerçekleşmektedir. PDX1, pankreas gelişimi ve beta hücre farklılaşması üzerine önemli role sahip bir transkripsiyon faktörüdür. MafA ise insülin gen transkripsiyonunun potansiyel bir uyarıcisıdır. Laboratuvar çalışmalarında, beta hücreler ve ratlardan izole edilen adacık hücrelerinin oksidatif strese maruziyeti sonucunda, bu transkripsiyon faktörlerinin insülini uyarıcı aktivitelerinin azaldığı ve insülinin mRNA ekspresyonunun baskılandığı gösterilmiştir (25). Bunun yanı sıra oksidatif stres, beta hücrelerdec-Jun N-terminal kinaz(JNK) yolağının aktivitesini de uyarabilmektedir. JNK yolağı, hücrelerde spesifik transkripiyon faktörlerinin aktivasyonu vasıtasıla pro-apoptik genlerin uyarılmasından sorumludur (26). Beta hücrelerde artan oksidatif stresin bir sonucu olarak aktif hâle gelen JNK yolağı, beta hücrelerin ölümü ve nicel olarak azalmasıly sonuçlanır (24). Beta hücreleri, pro-oksidanlara karşı oldukça hassastır. Grankvist ve ark. (27), yaptıkları bir çalışmada, pankreatik ada hücrelerinin oransal olarak daha az miktarda antioksidan enzim içeriğine sahip olduklarını göstermiştir. Çalışmaya göre beta hücrelerde CuZn süperoksit dismutaz (SOD), Mn-SOD, katalaz ve glutatyon peroksidaz enzimleri daha az bulunmuştur. Bu sebeple beta hücrelerinde hiperglisemi kaynaklı ROS üretiminin artışı, 
antioksidan enzimlerden zengin dokulara göre oksidatif stres oluşturmaya daha meyillidir.

\section{Oksidatif Stresin İnsülin Direnci Üzerine Etkisi}

Tip 2 diyabet oluşumunda pankreatik beta hücre hasarı kadar insülin direnci de etkili olabilmektedir. Hiperglisemik koşullarda karaciğer, kas ve yağ dokusu gibi insülinin hedef organları, insüline dirençli hâle gelir. Birden fazla hücresel çalışmada, oksidatif stres koşulları altında, hücrede insülin sinyalizasyonunun bozulduğu ve bunun bir sonucu olarak insülin direnci oluştuğu gösterilmiştir (28). Oksidatif stres, insülinin uyardığ 1 , IRS-1 (insülin reseptör substrat 1) ve PI3-K (fosfotidilinositol 3-kinaz) proteinlerinin ve GLUT4 taşıyıcı proteininin aktivitesini ve hücresel dağılımını bozarak, insülin direnci oluşumunda aktif rol oynayabilmektedir. (24).

Hücredeki insülin aktivitesi, insülinin hücre membranındaki reseptörünün alfa subunitine bağlanmasıyla başlar. İnsülin, hücre dışındaki alfa subunitine bağlandığında, hücre içindeki beta subunitinde tirozin kinaz aktivitesi uyarılır. Tirozin kinaz aktif hâle geldiğinde, beta subunite bağlı insülin reseptör substratlarını (IRS) fosforile eder. Tirozin fosforile olmuş IRS proteinleri, Src-homoloji -2 (SH-2) bağlanma bölgelerini içeren fosfatidil inositol 3-kinaz (PI3K) proteinine bağlanır. PI3K, insülinin metabolik ve mitojenik etkilerinin ana sinyal aracıdır. Tirozin fosforile olmuş IRS proteinlerinin PI3K'ye bağlanmasılya, glikoz taşıyıcı proteinlerin (GLUT) hücre membranına hareketi sağlanır ve glikozun hücre içine taşınımı gerçekleşir (29). Kronik oksidatif stres, NF-ks, JNK/SAPK ve p38 gibi bir dizi strese duyarlı sinyal yolağını indükleyerek, IRS proteinlerinin tirozin fosforilasyonunu bozar. NF-kB, JNK/SAPK ve $\mathrm{p} 38$, serin/treonin protein kinaz ailesine mensup proteinlerdir ve bu kinazlar stres, inflamatuar sitokinler gibi hücresel uyarıcılara tepki olarak aktive olabilirler. Aktif serin/treonin kinazlar, insülinin sinyal yolağındaki IRS proteinlerini, serin/treonin fosforile ederek tirozin fosforilasyonunu sekteye uğratır. IRS'lerin serin fosforilasyonu, PI3K ile etkileşime girerek sinyal molekülleri oluşturma yeteneğini bozar (30). Bouzakri ve ark.nın yaptığg çalışmada (31), insan iskelet kası hücrelerinde meydana gelen insülin direncinin, artmıs IRS-1 serin fosforilasyonu ile ilişkili olduğu gösterilmiştir. Oksidatif stres koşullarında ayrıca, GLUT4'ün gen transkripsiyonu ve hücresel dağılımı değişir ve insülin sinyalizasyonu bozulabilir (30). Hayvan çalışmalarında, $\mathrm{H}_{2} \mathrm{O}_{2}$ 'ye maruz bırakılan L6 miyotüpler ve 3T3-L1 adipositlerinde, GLUT4'ün mRNA ve protein seviyelerinde anlamlı bir düşüş gözlemlenmiştir (32). Bu düşüş, hücreye glikoz alımının azalması ve sonuç olarak insülin direnci gelişimiyle sonuçlanacaktır.

\section{OKSIDDATIFF STRES VE DİYABET KOMPLİKASYONLARI}

Oksidatif stres, hedef dokularda hücresel hasara sebebiyet vererek diyabetin kronik komplikasyonlarının (retinopati, nefropati, nöropati, koroner arter hastalıkları) oluşumunda rol oynayabilir. Yukarıda anlatılan gliko-oksidatif stres kaynaklı beş yolak, genel olarak diyabet komplikasyonlarının patogenezinin temelinde yatar.

Diyabetle ilişkili mortalite ve morbiditenin en önemli paydaşı kardiyovasküler hastalıklardır. Hiperglisemiye bağlı artış gösteren ileri glikasyon son ürünleri (AGE), koroner hasar oluşumunda majör role sahiptir. Gliko-oksidatif stres sonucu DNA, protein ve lipit gibi hücresel bileşenler hasara uğrar ve hücresel homeostaz bozulur. Oluşan hasarlı moleküller, endotelyal hücre ve kardiyomiyosit fonksiyonunu ve kardiyovasküler reaktiviteyi bozarak makrovasküler komplikasyonların ortaya çıkmasında etkili olur (33).

Diyabetik nefropati, kronik böbrek hastalıklarının en sık nedenlerinden biri olmakla birlikte, tip 1 DM'li hastaların \%30'u, tip 2 DM'li hastaların \%25'ini etkileyen bir komplikasyondur (18). Gliko-oksidatif stres, AGE oluşumunun artışına, polyol ve heksozamin yolaklarına glikoz akışının artışına, NF-kB yolağının uyarılmasına, renin-anjiyotensin-aldosteron sisteminin etkinliğinin artmasına sebep olur. Tüm bu faktörler bir arada, hücre hasarına, podositlerin apoptozisine ve böbreklerde ekstrasellüler matrix proteinlerinin birikimine sebep olarak normal böbrek fonksiyonunu bozar (33).

Diyabetik retinopati dünyada, görme bozukluğunun en önemli sebeplerinden biridir. Hastalığın patogenezinde, perisit kaybı, bazal membran kalınlaşması, mikroanevrizmalar, neovaskülarizasyon ve kan retina bariyerinin bozulması yer almaktadır. Diyabetik retinopatide rol oynayan moleküler ve biyokimyasal mekanizmalar arasında, polyol ve heksozamin yolaklarına glikoz akışının artması, PKC yolağının aktivasyonu ve AGE oluşumu sayılabilir. Özellikle polyol yolağına glikoz akışının artışı, retinada sorbitol birikimiyle sonuçlanarak, osmotik basinca sebep olur. Retinal osmotik stres, hastalık patogenezi ve klinik tablonun oluşmasında aktif rol oynar (34).

Diyabetik nöropati, tüm diyabet hastalarının \%60-70'ini etkileyebilen ciddi komplikasyonlardan bir diğeridir. Nöropati, beyin ve sinir sisteminin hassas bölgelerini etkileyerek fonksiyonel kayıp ve demans ile sonuçlanabilir. Reaktif oksijen türevleri varlığında etkinliği artan glikooksidatif yolaklar, nöronlarda ve Schwann hücrelerinde, NF- $\kappa B$ ve mitojen-aktive protein kinazları (MAPK) uyararak hücresel hasar ve apoptozise yol açarak nöropati oluşumunu tetikleyebilir (35). 


\section{DIYYABETIKK BİREYLERDE OKSİDATIFF STRESIN BELIRLENMESI}

Oksidatif hasarın laboratuvar ortamında tayini, sağlık taramaları, koruyucu tıp hizmetlerinin geliştirilmesi, çeşitli hastalıklar için risk faktörlerinin belirlenmesi, hastalıkların tahmini, ilaç ve diyet etkisinin gözlemlenmesindeki olası faydalarından ötürü sağlık personeline önemli klinik girdiler sağlar. Son yıllarda oksidatif stres kaynaklı hastalıklarda (kalp-damar hastalıkları diyabet gibi) görülen artış sebebiyle, bu hastalarda oksidatif stresi yansitan pek çok belirteç tanımlanmıș ve konuyla ilgili pek çok çalıșma yapılmıștır (36-40). Reaktif türevlerin hücre bileșenleriyle verdikleri tepkimeler sonucu oluşan metabolitler, oksidatif hasar tayininde sıklıkla kullanılan belirteçlerdir. Lipit, protein ve DNA hasarı sırasında oluşan son ürün veya ara ürünler, dokuya özgü veya tüm vücut oksidatif hasarı hakkında bilgi verebilir.

Reaktif türevlerin lipitlerle verdiği reaksiyon sonucu oluşan lipit peroksitleri, kanda ve idrarda gözlemlenebilen reaktif yan ürünlerin oluşumuna katılabilirler. Lipit peroksidasyonunun en yaygın ara ürünleri arasında malonaldehit (MDA), 4-hidroksinonenal (4-HNE) ve 8-iso-prostoglandin F2-a (8-isoprostane) sayllabilir (33). Zujko ve ark.nın yaptığ çalışmada (41), MDA ve 4-hidroksi alkenal seviyelerinin sağlıklı bireylerde diyabetli bireylere göre; yeni tanılı bireylerde ise eski tanılı bireylere göre daha düşük olduğu gözlemlenmiştir. Zhang ve ark.nın yaptığı çalışmada (42) ise yüksek 8-iso-prostoglandin F2-a seviyelerinin diyabetik retinopati oluşumu ve seyrine katkısının olabileceği vurgulanmıştır.

Hücresel proteinler de lipitlere benzer şekilde oksidatif hasara karşı hassastır. Reaktif türevlerin varlığında, amino asit rezidüleri, oksidasyon veya nitrasyona uğrayabilir. Plazma protein karbonilleri (PPK) ve ileri oksidasyon protein ürünleri (İOÜ), vücutta oksidatif protein hasarını değerlendirmede sıklıkla kullanılan belirteçlerdendir (33). Pandey ve ark.nın yaptığı çalışmada (43), diyabetik bireylerde PPK ve İOPÜ'nün sağlıklı bireylere göre daha yüksek olduğu, diyabetik bireylerin protein oksidasyonuna karşı daha hassas olabileceği belirtilmiştir.

DNA, oksidatif stresin bir diğer ve biyolojik olarak en önemli hedeflerinden biridir. DNA ve RNA hasarı diyabetin de içinde olduğu pek çok kronik ve dejeneratif hastalık ile ilişkilendirilmiştir (44). Nükleik asit hasarını yansıtmada pek çok molekül tanımlanmış olmakla birlikte en yaygın belirteçler arasında 8-hidroksi-guanin (8-OHG) ve 8 -hidroksi-2'-deoksiguanozin (8-OHdG) sayllabilir (33). Diyabette, reaktif türlerin artışına bağlı olarak DNA hasarı ve 8-OHdG atımı da artış gösterir. Liu ve ark. nın yaptığ 1 çalışmada (45) tip 2 diyabetli hastalar, tip 2 diyabete eşlik eden komplikasyonları olan hastalar ile sağlıklı bireyler karşılaştırıldığında; komplikasyonları olan bireylerin olmayanlara göre; hasta bireylerin ise sağlıklı bireylere göre idrarla 8-OHdG atımının daha yüksek olduğu gözlemlenmiştir. Pan ve ark.nın çalışmasında (46) ise, diyabet süresi ve idrarla 8 -OHdG atımı pozitif ilişkili bulunmuştur.

\section{SONUÇ}

Oksidatif stresin, vücutta enerji üretim mekanizmalarının olağan çalışma prensiplerini bozabildiği ve hücrenin genel çalışma prensiplerini etkiyebildiği çeşitli çalışmalarla kanıtlanmıştır. Bu bağlamda, oksidan mekanizmaların diyabet ve komplikasyonlarının gelişimindeki metabolik ve biyokimyasal alt yapısını kavrayabilmek ve ölçülebilir sonuçlarını yorumlayabilmek, geliştirilebilecek etkin tedavi yöntemlerinin ortaya çıkışına katkı sağlayacaktır. Rutinde oksidatif stresi azaltmaya yönelik özelleşmiş tedavi stratejileri bulunmasa da antioksidanların bu konuda etkinlik sağlayabildiği düşünülmektedir. $\mathrm{Bu}$ alanda daha derinlemesine yapılacak çalışmalar ve geliştirilecek tedavi yöntemleri, diyabetin olumsuz etkilerinin kontrol altına almasına destek sağlayacaktır.

Çıkar Çatışması

Yazarlar arasında herhangi bir çıkar çatışması yoktur.

Yazarların Makaleye Katkı Beyanı

Yazarlar makaleye eşit oranda katkı sağlamışlardır.

\section{KAYNAKLAR}

1. Robertson RP. Chronic oxidative stress as a central mechanism for glucose toxicity in pancreatic islet beta cells in diabetes. J Biol Chem. 2004;279(41):42351-42354.

2. Wright E, Scism-Bacon JL, Glass LC, Glass L. Oxidative stress in type 2 diabetes: The role of fasting and postprandial glycaemia. Int J Clin Pract. 2006;60(3):308-314.

3. Yan L-J. Pathogenesis of chronic hyperglycemia: From reductive stress to oxidative stress. J Diabetes Res. 2014;2014:137919.

4. Lorenzi M. The polyol pathway as a mechanism for diabetic retinopathy: Attractive, elusive, and resilient. Exp Diabetes Res. 2007;2007:61038.

5. Tang WH, Martin KA, Hwa J. Aldose reductase, oxidative stress, and diabetic mellitus. Front Pharmacol. 2012;3:87.

6. Lee AY, Chung SS. Contributions of polyol pathway to oxidative stress in diabetic cataract. FASEB J. 1999;13(1):2330 . 
7. Drel VR, Pacher P, Ali TK, Shin J, Julius U, El-Remessy AB, Obrosova IG. Aldose reductase inhibitor fidarestat counteracts diabetes-associated cataract formation, retinal oxidativenitrosative stress, glial activation, and apoptosis. Int J Mol Med. 2008;21(6):667-676.

8. Giacco F, Brownlee M. Oxidative stress and diabetic complications. Circ Res. 2010;107(9):1058-1070.

9. Ramirez MA, Borja NL. Epalrestat: An aldose reductase inhibitor for the treatment of diabetic neuropathy. Pharmacotherapy. 2008;28(5):646-655.

10. Giannoukakis N. Drug evaluation: ranirestat--an aldose reductase inhibitor for the potential treatment of diabetic complications. Curr Opin Investig Drugs. 2006;7(10):916-923.

11. Johnson BF, Nesto RW, Pfeifer MA, Slater WR, Vinik AI, Chyun DA, Law G, Wackers FJ, Young LH. Cardiac abnormalities in diabetic patients with neuropathy: Effects of aldose reductase inhibitor administration. Diabetes Care. 2004;27(2):448-454.

12. Schleicher ED, Weigert C. Role of the hexosamine biosynthetic pathway in diabetic nephropathy. Kidney Int. 2000;58(77):1318.

13. Pantaleon M, Tan HY, Kafer GR, Kaye PL. Toxic effects of hyperglycemia are mediated by the hexosamine signaling pathway and o-linked glycosylation in early mouse embryos. Biol Reprod. 2010;82(4):751-758.

14. Semba RD, Huang H, Lutty GA, Van Eyk JE, Hart GW. The role of O-GlcNAc signaling in the pathogenesis of diabetic retinopathy. Proteomics Clin Appl. 2014;8(3-4):218-231.

15. Horal M, Zhang Z, Stanton R, Virkamäki A, Loeken MR. Activation of the hexosamine pathway causes oxidative stress and abnormal embryo gene expression: Involvement in diabetic teratogenesis. Birth Defects Res Part A - Clin Mol Teratol. 2004;70(8):519-527.

16. Yang X, Ongusaha PP, Miles PD, Havstad JC, Zhang F, So WV, Kudlow JE, Michell RH, Olefsky JM, Field SJ, Evans RM. Phosphoinositide signalling links O-GlcNAc transferase to insulin resistance. Nature. 2008;451(7181):964-969.

17. Cooksey RC, Hebert LF, Zhu JH, Wofford P, Garvey WT, McClain DA. Mechanism of hexosamine-induced insulin resistance in transgenic mice overexpressing glutamine: fructose-6-phosphate amidotransferase: Decreased glucose transporter GLUT4 translocation and reversal by treatment with thiazolidinedione. Endocrinology. 1999;140(3):11511157.

18. Soetikno V, Watanabe K, Lakshamanan AP, Arumugam S, Sari FR, Sukumaran V, et al. Role of protein kinase C-MAPK, oxidative stress and inflammation pathways in diabetic nephropathy. J Nephrol Ther. 2012;s2(1).

19. Geraldes P, King GL. Activation of protein kinase C isoforms and its impact on diabetic complications. Circ Res. 2010;106:1319-1331.

20. Luo X, Wu J, Jing S, Yan LJ. Hyperglycemic stress and carbon stress in diabetic glucotoxicity. Aging Dis. 2016;7(1):90-110.
21. Khaled A, Ahmed Ikram SSM. Type 2 diabetes and vascular complications: A pathophysiologic view. Biomed Res. 2010;21(2):147-115.

22. Lind M, Odén A, Fahlén M, Eliasson B. The true value of HbAlc as a predictor of diabetic complications: Simulations of HbA1c variables. PLoS One. 2009;4(2):e4412.

23. Nagai R, Murray DB, Metz TO, Baynes JW. Chelation: A fundamental mechanism of action of AGE inhibitors, AGE breakers, and other inhibitors of diabetes complications. Diabetes. 2012;61(3):549-559.

24. Kaneto H, Matsuoka T, Katakami N, Kawamori D, Miyatsuka T, Yoshiuchi K, Yasuda T, Sakamoto K, Yamasaki Y, Matsuhisa $\mathrm{M}$. Oxidative stress and the JNK pathway are involved in the development of type 1 and type 2 diabetes. Curr Mol Med. 2007;7(7):674-686.

25. Tabak O, Gelisgen R, Erman H, Erdenen F, Muderrisoglu C, Aral H, Uzun H. Oxidative lipid, protein, and DNA damage as oxidative stress markers in vascular complications of diabetes mellitus. Clin Invest Med. 2011;34(3):E163-171.

26. Dhanasekaran DN, Reddy EP. JNK signaling in apoptosis. Oncogene. 2008;27(48):6245-6251.

27. Grankvist K, Marklund SL, Taljedal IB. CuZn-superoxide dismutase, $\mathrm{Mn}$-superoxide dismutase, catalase and glutathione peroxidase in pancreatic islets and other tissues in the mouse. Biochem J. 1981;199:393-398.

28. Eriksson JW. Metabolic stress in insulin's target cells leads to ROS accumulation - A hypothetical common pathway causing insulin resistance. FEBS Lett. 2007;581(19):3734-3742.

29. Draznin B. Molecular mechanisms of insulin resistance: Serine phosphorylation of insulin receptor substrate- 1 and increased expression of p85 a: The two sides of a coin. Diabetes. 2006;55(8):2392-2397.

30. Rains JL, Jain SK. Oxidative stress, insulin signaling, and diabetes. Free Radic Biol Med. 2011;50(5):567-575.

31. Bouzakri K, Karlsson HKR, Vestergaard H, Madsbad S, Christiansen E, Zierath JR. IRS-1 serine phosphorylation and insulin resistance in skeletal muscle from pancreas transplant recipients. Diabetes. 2006;55(3):785-791.

32. Bloch-Damti A, Bashan N. Proposed mechanisms for the induction of insulin resistance by oxidative stress. Antioxid Redox Signal. 2005;7(11-12):1553-1567.

33. Yang H, Jin X, Kei Lam CW, Yan SK. Oxidative stress and diabetes mellitus. Clin Chem Lab Med. 2011;49(11):17731782.

34. Safi SZ, Qvist R, Kumar S, Batumalaie K, Ismail IS. Molecular mechanisms of diabetic retinopathy, general preventive strategies, and novel therapeutic targets. Biomed Res Int. 2014;2014:801269.

35. Preedy VR. Aging: Oxidative Stress and Dietary Antioxidants, 1st Edition, Cambridge, Academic Press, 2014. p. 3-13.

36. Valavanidis A, Vlachogianni T, Fiotakis C. 8-Hydroxy-2' -deoxyguanosine (8-OHdG): A critical biomarker of oxidative stress and carcinogenesis. J Environ Sci Heal - Part C Environ Carcinog Ecotoxicol Rev. 2009;27(2):120-139. 
37. Martín-Gallán P, Carrascosa A, Gussinyé M, Domínguez C. Biomarkers of diabetes-associated oxidative stress and antioxidant status in young diabetic patients with or without subclinical complications. Free Radic Biol Med. 2003;34(12):1563-1574.

38. Bloomer RJ, Fisher-Wellman KH. Blood oxidative stress biomarkers: Influence of sex, exercise training status, and dietary intake. Gend Med. 2008;5(3):218-228.

39. Il'yasova D, Scarbrough P, Spasojevic I. Urinary biomarkers of oxidative status. Clin Chim Acta. 2012;413(19-20):1446-1453.

40. Frijhoff J, Winyard PG, Zarkovic N, Davies SS, Stocker R, Cheng D, Knight AR, Taylor EL, Oettrich J, Ruskovska T, Gasparovic AC, Cuadrado A, Weber D, Poulsen HE, Grune T, Schmidt HH, Ghezzi P. Clinical relevance of biomarkers of oxidative stress. Antioxid Redox Signal. 2015;23(14):11441170.

41. Zujko ME, Witkowska AM, Górska M, Wilk J, Krętowski A. Reduced intake of dietary antioxidants can impair antioxidant status in type 2 diabetes patients. Pol Arch Med Wewn. 2014;124(11):599-607.
42. Zhang Y, Du Y, He JF, Li KJ. 8-iso-prostaglandin-F2a: A possible trigger or accelerator of diabetic retinopathy. Int J Ophthalmol. 2016;9(1):163-165.

43. Pandey KB, Mishra N, Rizvi SI. Protein oxidation biomarkers in plasma of type 2 diabetic patients. Clin Biochem. 2010;43(45):508-511.

44. Chao MR, Rossner P, Haghdoost S, Jeng HA, Hu CW, Hu CW. Nucleic acid oxidation in human health and disease. Oxid Med Cell Longev. 2013;2013:368651.

45. Liu X, Gan W, Zou Y, Yang B, Su Z, Deng J, Wang L, Cai J. Elevated levels of urinary markers of oxidative DNA and RNA damage in Type 2 diabetes with complications. Oxid Med Cell Longev. 2016;2016:4323198.

46. Pan H, Zhang L, Guo M, Sui H, Li H, Wu W, Qu NQ, Liang $\mathrm{MH}$, Chang D. The oxidative stress status in diabetes mellitus and diabetic nephropathy. Acta Diabetol. 2010;47(S1):71-76. 